\title{
THE EFFECT OF OESTROGEN AND ANTI- OESTROGENS ON OVUM TRANSPORT IN MICE
}

\author{
K. HUMPHREY AND L. MARTIN* \\ Department of Veterinary Physiology, University of Sydney, Australia
}

(Received 15th December 1966)

\begin{abstract}
Summary. Oestradiol-17 $\beta$, dimethylstilboestrol (DMs), MER-25 and MRL-37 given on Days 1 to 3 of pregnancy caused retention of ova in the oviduct. None of the compounds increased the numbers of overtly abnormal ova although they all increased the proportion of morulae to blastocysts found on Day 4. This apparent delay in development was not observed when ova were retained by ligation. Although it seems likely that the anti-oestrogens were effective by virtue of their oestrogenic properties they did not reduce the numbers of ova recovered, whereas oestradiol-17 $\beta$ did. The mechanism whereby ova are lost is not clear.
\end{abstract}

\section{INTRODUCTION}

It has been shown that certain anti-oestrogens related to diethylstilboestrol prevent pregnancy in laboratory animals when given on Days 1 to 3 (Martin, Emmens \& Cox, 1960). The anti-fertility action of such compounds was at first ascribed to their anti-oestrogenic properties (Emmens, Cox \& Martin, 1962), but is now thought to be an oestrogenic action (Emmens, 1964, 1965). The weak anti-oestrogen MER-25 (Lerner, Holthaus \& Thompson, 1958) also prevents pregnancy, although it is thought to act by a specific cytotoxic action on the developing zygote in the oviduct (Segal \& Nelson, 1958).

It was thought that a more detailed study of these compounds' effects on ovum transport and development might help elucidate their mode of action. The following is a report of some preliminary experiments in this direction.

\section{MATERIALS AND METHODS}

Randomly bred QS mice were housed at $72^{\circ} \mathrm{F}$ with automatic lighting from 06.00 to 18.00 hours. Mature females were placed overnight with fertile males and were examined each morning for copulation plugs. Females with plugs were randomly placed five per box; within each box the mice were allotted to the five treatment groups at random. The day of finding a plug was termed Day 1 of pregnancy.

The compounds were administered subcutaneously in $0.1 \mathrm{ml}$ of peanut oil at noon on Days 1, 2 and 3; control mice received oil only. Dimethylstilboestrol

\footnotetext{
* Present address: Imperial Cancer Research Fund, Lincoln's Inn Fields, London.
} 
(DMs) was the preparation used by Martin, et al. (1960) ; 1-( $p$-2-diethylaminoethoxyphenyl)-1-phenyl-2-anisyl-ethanol (MER-25) and the corresponding ethane (MRL-37) were supplied by the Merrell Company.

Mice were killed on Day 4 or 5 and the reproductive tracts dissected free. They were identified by random number only, to preclude any bias by the observer. Each oviduct was separated from the uterine horn at the utero-tubal junction. The uterine contents were flushed into a cavity slide with $0.25 \mathrm{ml}$ of medium. The oviducts were flushed, under a dissecting microscope, with a blunt 30 gauge needle inserted in the ovarian os. The washings were examined under the dissecting microscope and the ova counted. The ova were transferred by micro-pipette to a clean slide and examined by phase contrast microscopy at a magnification of 200 .

Normal ova were classified as morulae if the blastocoele was absent or occupied less than one-quarter of the vitellus, otherwise as blastocysts. In preliminary experiments, flushing of the oviducts was a slow procedure and the ova were in $0.9 \% \mathrm{NaCl}$ for up to $4 \mathrm{hr}$ before examination and classification. Many morulae from the oviduct had small irregular cavities and uneven blastomeres and were thought to be abnormal. Whitten (personal communication) suggested that these features resulted from the prolonged sojourn in saline. In the present experiments, Krebs-Ringer phosphate buffer ( $\mathrm{pH} 7.4$ ) with $1 \%$ bovine serum albumin was used. With an improved flushing technique the washings were examined within $1 \mathrm{hr}$. Under these conditions, the morulae were well preserved and appeared to be normal.

Abnormal ova were classified as unfertilized or fragmenting. The apparently unfertilized eggs found solely in the oviduct sometimes had cumulus cells and were, perhaps, due to a second ovulation (Whitten, personal communication).

Fragmenting ova were found in both uterus and oviduct. All stages of degeneration were seen, ranging from ova with irregular-shaped blastomeres to zonae filled with debris; such ova could arise from unfertilized eggs or from zygotes that had initially cleaved normally.

Corpora lutea were examined only cursorily, no counts were made, and absolute estimates of ovum losses could not be made. However, within the limits of experimental error equal numbers of ova would be expected from each group.

A number of oviducts were examined histologically. In these cases mice received $0.4 \mu \mathrm{g}$ of oestradiol- $17 \beta$ in oil or $0.1 \mathrm{ml}$ of peanut oil on Days 1 and 2 and were killed on Day 3. The oviducts were fixed in Bouin's solution and embedded in paraffin wax. Serial sections $(6 \mu)$ were stained in Heidenhain's haematoxylin and Van Gieson's picro-fuchsin.

\section{RESULTS}

The effects of oestradiol-17 $\beta(0.4 \mu \mathrm{g} /$ day $)$, DMs (100 $\mu \mathrm{g} /$ day) MER-25 (2.0 $\mathrm{mg} /$ day) and MRL-37 (2.0 mg/day) on the distribution of ova are shown in Table 1. In oil-treated animals the majority of ova were recovered from the uterus. DMs, MER-25 and MRL-37 all reduced the numbers of uterine ova and correspondingly increased the numbers of tubal ova. None of the anti-oestrogens 
affected overall recovery. In contrast oestradiol-17 $\beta$ greatly reduced the number of ova recovered; it increased the numbers of tubal ova to almost the same extent as the anti-oestrogens, but reduced the numbers in the uterus to a much greater extent.

TABLE 1

THE EFFECTS OF OESTRADIOL- $17 \beta$ AND ANTIOESTROGENS ON THE DISTRIBUTION OF MOUSE OVA ON DAY 4 OF PREGNANGY

\begin{tabular}{l|c|c|c}
\hline \multicolumn{1}{c|}{ Treatment } & Oviduct & Uterus & Total \\
\hline Peanut oil & $1 \cdot 80$ & $6 \cdot 46$ & $8 \cdot 26$ \\
Oestradiol-17 & $4 \cdot 37$ & $0 \cdot 23$ & $4 \cdot 60$ \\
DMS & $7 \cdot 14$ & 0.97 & $8 \cdot 11$ \\
MRL-37 & $7 \cdot 34$ & $1 \cdot 17$ & $8 \cdot 51$ \\
MER-25 & $4 \cdot 54$ & $4 \cdot 63$ & $9 \cdot 17$ \\
\hline
\end{tabular}

Summary of the analysis of variance

\begin{tabular}{l|cccc}
\hline \multirow{2}{*}{ Source of variation } & \multicolumn{4}{|c}{ Mean squares } \\
\cline { 2 - 5 } & $d f$ & Oviduct & Uterus & Total \\
\hline Control versus treatments & 1 & $459^{* * *}$ & $620^{* * *}$ & 12 \\
Oestradiol versus anti-oestrogens & 1 & $102^{*}$ & $108^{* *}$ & $420^{* * *}$ \\
DMS versus MRL-37 & 1 & 0 & 1 & 3 \\
DMs, MRL-37 versus MER-25 & 1 & $170^{* *}$ & $295^{* * *}$ & 17 \\
\hline Error & 170 & $17 \cdot 3$ & $10 \cdot 7$ & $17 \cdot 4$ \\
\hline
\end{tabular}

The results are expressed as mean number of ova/mouse with thirty-five mice/ group.

$$
\text { *0.01<P<0.05. **0.001 }<P<0.01 . \quad * * * P<0.001 \text {. }
$$

Table 2 shows the distribution of the various classes of ova in the different treatment groups. In no case were unfertilized ova recovered from the uterus. This was also true of mice killed on Day 5. These observations support the

TABLE 2

THE DISTRIBUTION OF THE VARIOUS GLASSES OF OVA ON DAY 4 OF PREGNANCY IN MICE TREATED WITH OESTROGEN OR ANTI-OESTROGEN

\begin{tabular}{l|c|cc|cc|cc}
\hline \multirow{2}{*}{ Treatment } & \multirow{2}{*}{ Unfertilized ova } & \multicolumn{2}{|c|}{ Fragmented ova } & \multicolumn{2}{|c|}{ Morulae } & \multicolumn{2}{|c}{ Blastocysts } \\
\cline { 2 - 6 } & Oviduct & Oviduct & Uterus & Oviduct & Uterus & Oviduct & Uterus \\
\hline Peanut oil & 0.69 & 0.57 & 0.54 & 0.51 & 2.00 & 0.03 & 3.91 \\
Oestradiol & 0.54 & 0.40 & 0.00 & 2.86 & 0.17 & 0.57 & 0.06 \\
DMs & 0.77 & 1.14 & 0.06 & 4.54 & 0.60 & 0.69 & 0.31 \\
MRL-37 & 0.83 & 0.43 & 0.06 & 5.40 & 0.97 & 0.69 & 0.14 \\
MER-25 & 0.71 & 0.17 & 0.60 & 3.40 & 1.66 & 0.26 & 2.37 \\
\hline
\end{tabular}

The results are expressed as the mean number of ova with thirty-five mice/group.

suggestion that such ova arose from a second ovulation. However, selective retention cannot be entirely excluded. Fragmenting ova were distributed in 
essentially the same way as the normal ova. The numbers of abnormal ova were not significantly increased by any of the treatments.

In control animals approximately two thirds of the normal ova were blastocysts and these were found almost exclusively in the uterus. Of the morulae, approximately four-fifths were found in the uterus. In all the treatment groups the zygotes were mostly morulae. Both morulae and blastocysts were found

TABLE 3

THE DISTRIBUTION OF THE VARIOUS GLASSES OF OVA ON DAY 5 OF PREGNANGY IN MIGE TREATED WITH OESTROGEN OR ANTI-OESTROGEN

\begin{tabular}{|c|c|c|c|c|c|c|c|}
\hline \multirow{2}{*}{ Treatment } & \multirow{2}{*}{$\frac{\text { Unfertilized ova }}{\text { Oviduct }}$} & \multicolumn{2}{|c|}{ Fragmented ova } & \multicolumn{2}{|c|}{ Morulae } & \multicolumn{2}{|c|}{ Blastocysts } \\
\hline & & Oviduct & Uterus & Oviduct & Uterus & Oviduct & Uterus \\
\hline $\begin{array}{l}\text { Oestradiol } \\
\text { DMS } \\
\text { MRL_-37 } \\
\text { MER-25 }\end{array}$ & $\begin{array}{l}0.50 \\
0.50 \\
1.25 \\
0.50\end{array}$ & $\begin{array}{l}0.25 \\
0 \cdot 13 \\
0.00 \\
0.37\end{array}$ & $\begin{array}{l}0.00 \\
0 \cdot 00 \\
0 \cdot 00 \\
0.37\end{array}$ & $\begin{array}{l}0 \cdot 50 \\
0 \cdot 50 \\
2 \cdot 00 \\
1 \cdot 25\end{array}$ & $\begin{array}{l}0.00 \\
0 \cdot 00 \\
0 \cdot 00 \\
0 \cdot 38\end{array}$ & $\begin{array}{l}1 \cdot 50 \\
0.50 \\
2 \cdot 75 \\
0 \cdot 13\end{array}$ & $\begin{array}{l}0.13 \\
0.50 \\
1.50 \\
3.63\end{array}$ \\
\hline
\end{tabular}

The results are expressed as the mean number of ova with eight mice/group.

primarily in the tube, except in animals treated with MER-25 where the blastocysts were predominantly uterine. In oestradiol-treated animals the numbers of morulae differed little from those in controls; thus, in this group, the increased proportion of morulae might result purely from the loss of blastocysts.

TABLE 4

THE EFFEGTS OF UNILATERAL LIGATION ON THE DEVELOPMENT OF MOUSE OVA

\begin{tabular}{l|c|c|c|c|c|c}
\hline & Unfertilized & $\begin{array}{c}\text { Fragmented } \\
\text { ova }\end{array}$ & $\begin{array}{c}\text { Total } \\
\text { abnormal }\end{array}$ & Morulae & Blastocysts & $\begin{array}{c}\text { Total } \\
\text { normal }\end{array}$ \\
\cline { 2 - 5 } & 1.38 & 1.00 & 2.38 & 0.38 & 3.69 & 4.07 \\
Ligated & 0.63 & 0.56 & 1.19 & 0.00 & $4 \cdot 13$ & $4 \cdot 13$ \\
\hline
\end{tabular}

Summary of the analyses of variance

\begin{tabular}{l|c|c|c|c}
\hline Source of variation & $d f$ & Abnormal & Normal & Total \\
\hline Ligation & 1 & $11 \cdot 3$ & $0 \cdot 0$ & $10 \cdot 1$ \\
Between mice & 15 & $3 \cdot 1$ & $48 \cdot 0$ & $2 \cdot 3$ \\
Residual(error) & 15 & $2 \cdot 8$ & $58 \cdot 0$ & $8 \cdot 1$ \\
\hline
\end{tabular}

The results are expressed as mean number of ova with sixteen animals/group. In the unligated tracts the unfertilized eggs were exclusively tubal-all else was uterine.

In the other treatment groups, however, loss of blastocysts was clearly not involved; here there was a real delay in development.

On Day 5 the normal ova of control animals have all developed to the blastocyst stage and have all reached the uterus. Implantation has proceeded far enough to prevent the recovery of blastocysts by flushing. Table 3, therefore, shows the distribution of ova on Day 5 in treated animals only. There was no 
obvious increase in the proportion of abnormal ova at this stage over that on Day 4, in any of the treatment groups. With the exception of the MER-25 group, the majority of the ova were recovered from the oviduct. In all groups approximately one-third of the normal ova were morulae and, again with the exception of the MER-25 group, these were recovered exclusively from the oviduct. Clearly the treatments have delayed the passage and the development of the ova, albeit incompletely.

Table 4 shows the recovery of ova and the numbers of morulae and blastocysts found on Day 4 in mice in which the right oviduct had been ligated at the utero-tubal junction at 16.00 hours on Day 1 . Mice without large hyperaemic corpora lutea, and those in which difficulty was experienced in flushing the ligated oviduct, were excluded from the results.

In the non-ligated horns all the normal ova (a total of sixty-six) had developed to blastocysts. In the ligated oviducts a small number were morulae (six of a total of sixty-five). This difference between the numbers of morulae in the ligated and non-ligated tracts is insufficient to account for the effects of the oestrogen and anti-oestrogens described above. These presumably resulted from something more than retention as such, perhaps effects on tubal secretions.

Sections from control animals killed on Day 3 showed morulae close together in the isthmus, near the utero-tubal junction. In sections from oestradioltreated mice all the ova were in the ampulla. There were no other obvious differences between oestradiol-treated and control animals.

\section{DISCUSSION}

Studies of oestrogens and ovum transport have given somewhat confusing results. In mice and rabbits, small doses of oestrone caused retention of zygotes in the oviduct (Burdick \& Pincus, 1935; Whitney \& Burdick, 1936) whereas large doses caused accelerated passage into the uterus (Burdick \& Whitney, 1937; Whitney \& Burdick, 1937). Greenwald (1957) found that $5 \mu \mathrm{g}$ oestradiol benzoate produced loss of ova in rabbits. Later (Greenwald, 1963), he found that $25 \mu \mathrm{g}$ oestradiol cyclopentyl propionate at coitus caused accelerated passage and loss, while $250 \mu \mathrm{g}$ caused retention. In the rat $10 \mu \mathrm{g}$ of oestradiol cyclopentyl propionate on Day 1 caused accelerated passage (Greenwald, 1961). Deanesly (1963) could not demonstrate tube-locking in guinea-pigs treated with $5 \mu \mathrm{g} /$ day of oestradiol benzoate. However, the recovery of ova was much reduced, this being attributed to premature passage to the uterus and subsequent degeneration or loss through the vagina.

In the present experiments the one level of oestradiol caused both retention and loss of ova in the same animal. Retention did not only involve blockage at the utero-tubal junction, since the ova were located in the ampulla. Clearly some ova did not reach the utero-tubal junction or, having done so, were returned to the ampulla. The position of these ova suggests that the low recovery in this group might result from loss to the bursa through the infundibulum. On the other hand some ova might pass through the tube relatively normally only to be lost from the uterus as a result of its increased motility under the influence of oestrogen. Experiments are in progress to answer these questions. 
Chang (1964) and Chang \& Yanagimachi (1965) showed that a number of anti-oestrogens interfered with ovum transport in rabbits, causing acceleration in some animals and retention in others. These authors considered that the anti-oestrogens were active by virtue of their oestrogenic properties. The present results tend to support this view; the anti-oestrogens behaved like oestradiol in that they caused retention of zygotes in the oviduct rather than acceleration. However, they differed from oestradiol in not causing significant loss of ova at the doses used, although they may do so at higher doses.

None of the compounds caused overt degeneration of ova, and here we differ from Segal \& Nelson (1958) and Chang (1959) who found that MER-25 caused degeneration of zygotes in rats and rabbits. However, many of the tube-locked mouse ova were retarded in development. This was not caused by retention as such since zygotes retained by ligation developed normally. Delayed development may result from actions of the compounds upon tubal secretions or directly upon the ova. Since this work was carried out preliminary experiments involving transfer of ova have indicated that they are viable and implant normally (Humphrey, in preparation).

\section{ACKNOWLEDGMENTS}

The authors are grateful to Professor G. W. Emmens for help and advice. The work was supported by grants from the Population Council (U.S.A.) and the Australia Wool Board. We are indebted to Dr W. K. Whitten for his assistance.

\section{REFERENCES}

Burdick, H. O. \& Pincus, G. (1935) The effect of oestrin injections upon the developing ova of mice and rabbits. Am. F. Physiol. 111, 201.

Burdick, H. O. \& Whitney, R. (1937) Acceleration of the rate of passage of fertilised ova through the fallopian tubes of mice by massive injections of an oestrogenic substance. Endocrinology, 21, 637.

Chang, M. C. (1959) Degeneration of ova in the rat and rabbit following oral administration of 1-( $p$-2-diethylamino-ethoxyphenyl)-1-phenyl-2-p-anisylethanol. Endocrinology, 65, 339.

Chang, M. C. (1964) Effects of certain anti-fertility agents on the development of rabbit ova. Fert. Steril. 15, 97.

Chang, M. C. \& Yanagimachi, R. (1965) Effect of oestrogens and other compounds as oral antifertility agents on the development of rabbit ova and hamster embryos. Fert. Steril. 16, 281.

DeanesLy, R. (1963) Further observations on the effects of oestradiol on tubal eggs and implantation in the guinea-pig. 7. Reprod. Fert. 5, 49.

Emmens, C. W. (1964) The oestrogenic and anti-fertility activities of diethylstilboestrol and dimethylstilboestrol in rodents. Acta endocr., Copenh. 49, 83.

EMmens, C. W. (1965) The oestrogenic, anti-oestrogenic and anti-fertility activities of various compounds. F. Reprod. Fert. 9, 277.

Emmens, C. W., Cox, R. I. \& Martin, L. (1962) Anti-oestrogens. Recent Prog. Horm. Res. 18, 415.

GREENWALD, G. S. (1957) Interruption of pregnancy in the rabbit by the administration of oestrogens. 7. exp. Zool. 135, 461.

GREENWALD, G. S. (1961) The anti-fertility effects in pregnant rats af a single injection of oestradiol cyclopentylpropionate. Endocrinology, 69, 1068.

GreEnwald, G. S. (1963) Interruption of early pregnancy in the rabbit by a single injection of oestradiol cyclopentylpropionate. F. Endocr. $26,133$.

Lerner, L. J., Holthaus, F. J., JR. \& Thompson, C. R. (1958) A non-steroidal oestrogen antagonist 1-(p-2-diethylaminoethoxyphenyl)-1-phenyl-2-p-methoxyphenyl ethanol. Endocrinology, 63, 295.

Martin, L., Emmens, C. W. \& Cox, R. I. (1960) The effect of oestrogens and anti-oestrogens on early pregnancy in mice. F. Endocr. 20, 299. 
Segal, S. J. \& Nelson, W. O. (1958) An orally active compound with anti-fertility effect in rats. Proc. Soc. exp. Biol. Med. 98, 431.

WhITNEY, R. \& BURDICK, H. O. (1936) Tube-locking of ova by oestrogenic substances. Endocrinology, 20,643 .

Whitney, R. \& Burdick, H. O. (1937) Acceleration of the rate of passage of fertilised ova through the fallopian tubes of rabbits by massive injections of Progynon B. Endocrinology, 22, 639. 